\title{
Contents, Vol. 2, 1976
}

International Journal for

Basic and Clinical Studies in Psychiatric Research

Editor:

J. Mendlewicz, Brussel]s/New

York, N.Y

J. de Ajuriaguerra, Paris

P. Janssens, Beerse

E.J. Sachar, Bronx, N.Y

1. Angst, Zurich

M. Jouvet, Lyon

M. Sandler, London

O.H. Arnold, Vienna

N. Sartorius, Geneva

C. Astrup, Tromsø

M. Schou, Risskov

M. Lipton,

J.R. Boissier, Paris
Chapel Hill, N.C.

J.R. Davis, Chicago, 111

l.l. Lopez Ibor, Madrid

P. Deniker, Paris

P. Mandel, Strasbourg
J. Smythies, Edinburgh

J.E. Desmedt, Brussels

N. Matussek, Munich

N. Matussek, Munich
E. Strömgren, Risskov

D. Kupfer, Pittsburgh, Pa.

M. Levitt, New York, N.Y.

T.A. Ban, Moṇtreal, Que.

F. Schulsinger, Copenhagen

C. Shagass, Philladelphia, Pa

H. Mitsuda, Osaka

R. Tissot, Geneva

Alttal,
T. Nagatsu, Nagoya

E. Usdin

A.E. Dresse, Lì̀ge

C.M. Pare, London

Rockville, Md.

W.G. Dewhurst, Edmonton,

I. Durrell, Washington, D.C! 
Chapel Hill, N.C

C. Perris, Umeà

P. Pichot, Paris

A. Villeneuve,

A.J. Prange, jr.

Beauport, Que.

S. Garattini, Milan

Chapel Hill, N.C

0. Vinar, Prague

L.R. Gjessing, Oslo

O.J. Rafaelsen,

M. Vojtëchovsky, Prague

J. Glowinski, Paris

Copenhagen

J.D. Rainer,

Iowa City, Iowa

P. Grof, Hamilton, Ont,

0. Hagnell, Lund

New York, N.Y.

E. Rìngel, Vienna

T. Helgason, Reykjavik 
No. 1

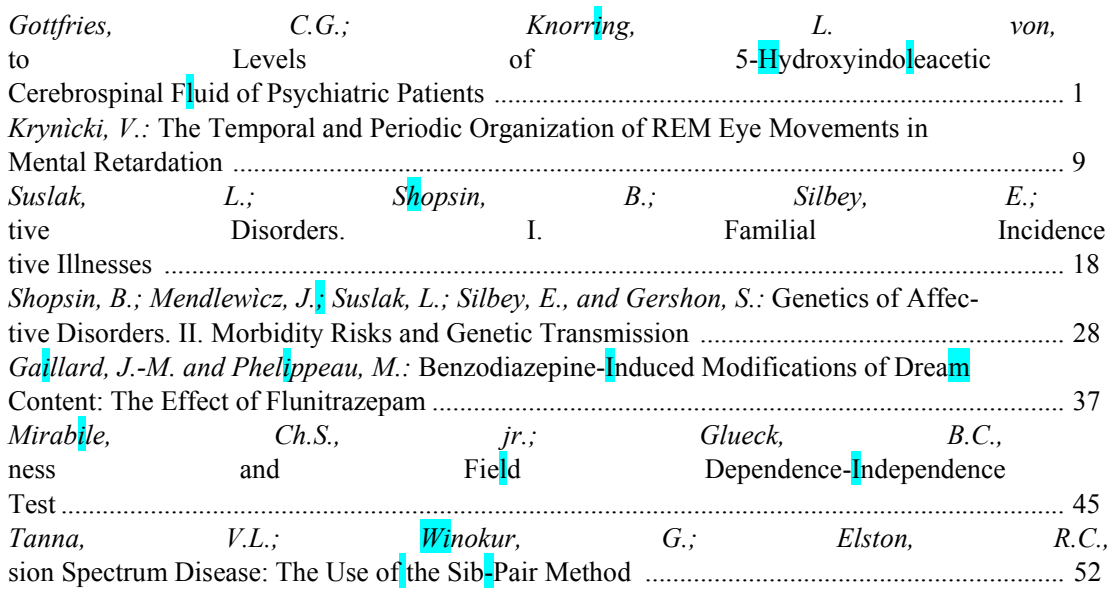

\section{No. 2-3}

Mendlewicz, J.: The Contribution of Genetics to Biological Psychiatry

Knorring, L. von; Oreland, L.; Perris, C, and Runeberg, S.: Lithium RBC/Plasma Ratio

in Subgroups of Patients with Affective Disorders

Dysken, M.; Evans, H.M.; Chan, C.H., and Davis, J.M.: Improvement of Depression and

Parkinsonism 1 .

Winokur, G.: Duration of Illness prior to Hospitalization (Onset) in the Affective

Disorder

Jacquy, J.; Wümotte, J.; Piraux, A., and Noël, G.: Cerebral Blood Flow Patterns

Studied by Rheoencephalography in Schizophrenia Index

Homma, A. andNielsen, J.: Chromosome Aneuploidy Associated with|Aging

Olesen, $O$. V. and Thomsen, K.: A Preventive Effect of Potassium against Fatal Lithium

Intoxication in Rats .................................................................................................... 112

Chouinard, G. and Annable, L.: $\alpha$-Methyldopa-Chlorpromazine Combination in

in

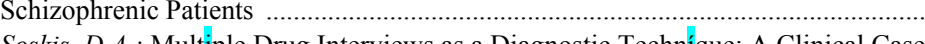

Study........

Olesen, O.V.; Schou, M., and Thomsen, K.: Administration of Lithium to Rats by

Different Routes ...........................................................................................

Hydroxylase Activity in Serum and Cerebrospinal Fluid in Neuropsychiatric Dis-

Gershon, S.; Shopsin, B., and Wilk, S.: Exploration of Affective Illness

Schou, M,: Bïbliography on the Biology and Pharmacology of Lithium. 4.

\section{No. 4}

Perel, J.M.; Mendlewicz, J.; Shostak, M.; Kantor, S.J., and Glassman, A.H.: Plasma Levels of Imipramine in Depression. Environmental and Genetic Factor

Dubois, M.; Scuvée-Moreau, J. et Dresse, A.: Essai d'enregistrement de Гactivité élec-

trophysiologique du locus cœruleus du rat

Geisler, A.; Bech, P.; Johannesen, M., and Rafaelsen, O.J.: Cyclic AMP Levels in

Cerebrospinal Fluid in Manic-Melancholic Patients

Roslund, B. and Larson, C.A.: Mentally Disturbed Violent Offenders in Sweden .... 221

Knorring $L$ von: Visual Averaged Evoked Responses in Patients Suffering from Alco-

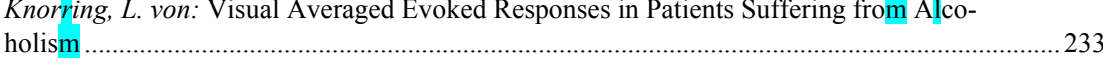

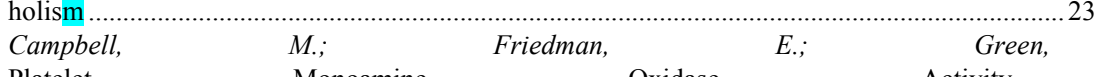

Campbell

Monoamine

Oxidase

Activity

lies. A Preliminary Study ................................................................................................ 239

Jain, M.: Neuropsychobiology of Affective Disorders. Some Methodological Consider

Crighel, E.; Predescu, V.; Matei, M.; Nica, S., and Prica, A.: Neocortical Reactivity to . . .165

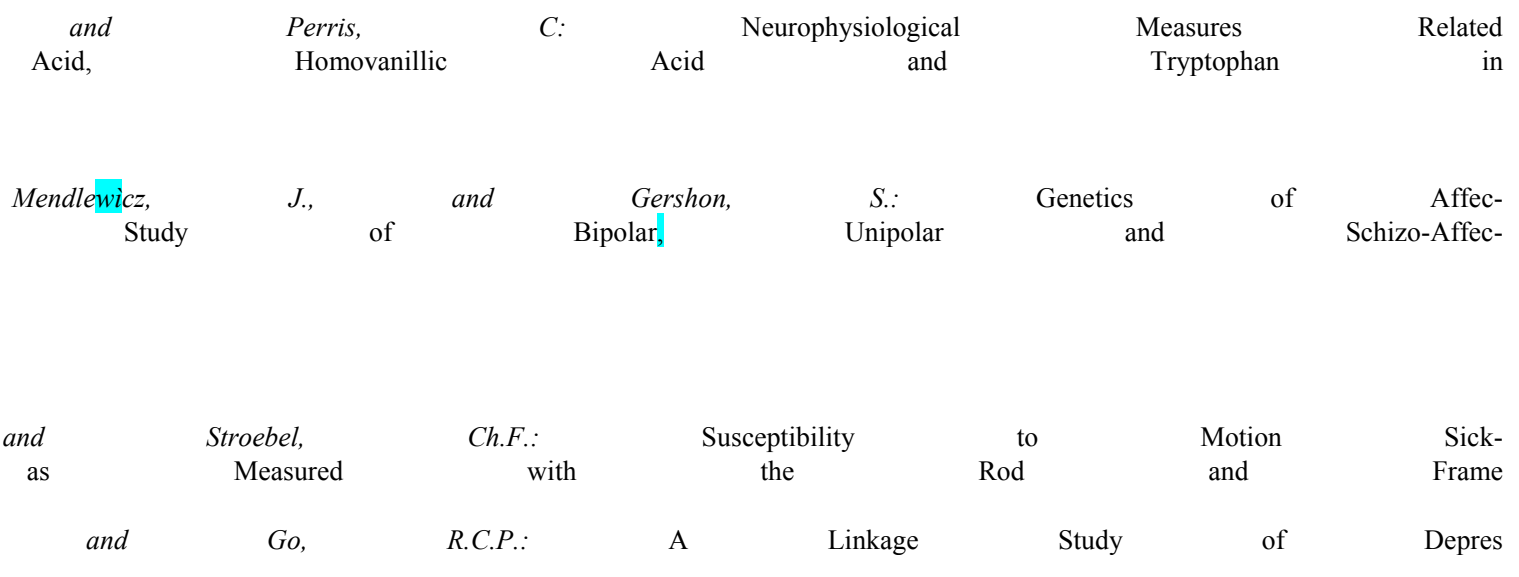

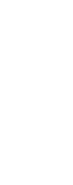


No. 5-6

Auman, J.R.; Sheffield, K.L., and Prange, A.J., jr.: Monoiodotyrosine: Effects on Tissue Amines and Cold Survival 277

Sannita, $W$. G.; Irvin, $P_{t}$, and Fink, M.: EEG and Task Performance after $\mathrm{ACTH}_{4.10}$ in

Rapoport, J.L.; Quinn, P.O.; Copeland, A.P., and Brug, C: $\mathrm{ACTH}_{4} \_10$ : Cognitive and

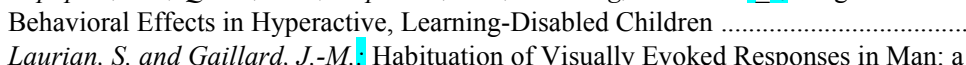

Study of its Time Course

Index

Branchey, L. and Friedhoff, A.J.: Effects of Repeated Administration of Morphine on Tyrosine Hydroxylase in the Rat Brain ....................................................................................307

Grof, P.; MacCrimmon, D.; Saxena, B.; Daigle, L., and Prior, M.: Bioavailability and

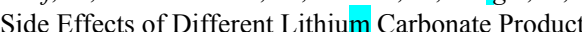

Biederman, J.; Rimon, R.; Ebstein, R.; Zohar, J., and Belmaker, R.: Neuroleptics

Reduce Spinal Fluid Cyclic AMP in Schizophrenic Patients ..................................

Spence, M.A.; Elston, R.C.; Namboodiri, K.K., and Rainer, J.D.: A Genetic Study
Schizophrenia Pedigrees. I. Demographic Studies: Sample Description, Age of

Onset, Ascertainment and Classification

324

Brambilla, F.; Guerrini, A.; Guastalla, A.; Beretta, P., and De Mailo, D,: Glucose-Insuli

Dornbush, R.L. and Volavka, J.: ACTH $\mathrm{AC}_{4-10}$ : a Study of Toxicological and Behavioral

Effects in an Aging Sample ...................................................................................

Procedures to Complex Evoked Potential Measurements in Psychiatric Research . 361

Book Reviews $\cdot$ Buchbesprechungen $\cdot$ Livres nouveaux

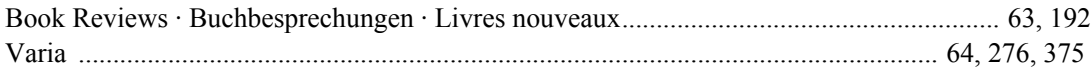

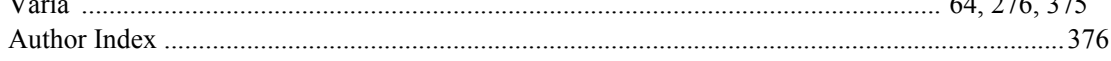

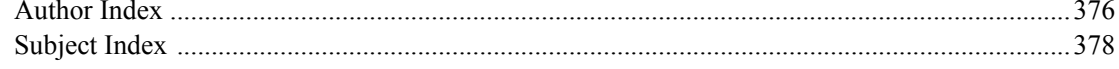

\section{All rights reserved}

No part of this publication may be translated into other languages, reproduced or utilized in any form or by any means, electronic or mechanical, including photocopy-ing, recording, microcopying, or by any information storage and retrieval system, without permission in writing from the publisher.

(c) Copyright 1976 by S. Karger AG, 4011 Basel (Switzerland), Arnold-Böcklin-Strasse 25 Printed in Switzerland by Thür AG Offsetdruck, Pratteln 